\title{
Preparation of (ruthenium (II) complex)-bound cellulose derivative for photocurrent generation system
}

\author{
Yasuko Saito $^{1} \cdot$ Hiroshi Kamitakahara ${ }^{1} \cdot$ Toshiyuki Takano $^{1}$
}

Received: 9 December 2015/ Accepted: 24 February 2016/Published online: 25 March 2016

(C) The Japan Wood Research Society 2016

\begin{abstract}
O$-[Acetylacetonato-bis(2,2'-bipyridine)ruthenium(II)]-2,3-di- $O$-myristyl cellulose (3) was prepared from 2,3-di- $O$-myristyl cellulose (1) by two reaction steps in $37.7 \%$ total yield. The LB monolayer film of compound $\mathbf{3}$ was successfully deposited onto an indium tin oxide electrode by a vertical dipping method and showed photocurrent generation performance in the range of 400-600 $\mathrm{nm}$. Compound 3 was expected as a complementary material of porphyrinbound cellulose derivative for biomaterial-based solar cells.
\end{abstract}

Keywords Cellulose $\cdot$ Langmuir-Blodgett film $\cdot$ Photoelectro conversion · Photosensitizer - Ruthenium complex

\section{Introduction}

Cellulose is the main component of wood. Numerous functional cellulose derivatives have been proposed for new applications [1-3]. However, attention is still focused on the development of the high-value added utilization for cellulose and its derivatives. From this point of the view, our group has reported that Langmuir-Blodgett (LB) films constructed from porphyrin-bound cellulose derivatives exhibited high photocurrent generation performances, suggesting that such cellulose derivatives are promising materials with potential applications in biomaterials-based solar cells $[4,5]$. However, the effective utilization of solar light by the LB films was insufficient, because the photocurrent was generated

Toshiyuki Takano

takatmys@kais.kyoto-u.ac.jp

1 Division of Forest and Biomaterials Science, Graduate School of Agriculture, Kyoto University, KitashirakawaOiwake-cho, Sakyo-ku, Kyoto 606-8502, Japan only at the range of the porphyrin absorption band from 400 to $420 \mathrm{~nm}$ as shown by spectrum (a) in Fig. 1, although the target wavelength range for an ideal solar cell should be considered from 300 to $1200 \mathrm{~nm}$ [6]. Therefore, other photosensitizer-bound cellulose derivatives which generate photocurrent at the unused region of solar light were strongly desired for the combination of the porphyrin-bound cellulose derivatives. In the previous papers, phthalocyanine- and squaraine-bound cellulose derivatives which covered photocurrent generation at the range from 650 to $720 \mathrm{~nm}$ [spectrum (b) in Fig. 1] and the range from 550 to $680 \mathrm{~nm}$ [spectrum (c) in Fig. 1] have been reported as the complementary materials of the porphyrin-bound cellulose derivatives (from 400 to $420 \mathrm{~nm}$ ), respectively [7-9]. However, the new photosensitizer-bound cellulose derivative was still required for the photocurrent generation performance at the range from 420 to $600 \mathrm{~nm}$ (Fig. 1).

Polypyridyl ruthenium (II) complexes, which are ruthenium coordination compounds with 2,2'-bipyridine ligands (bpy), are well-known as the panchromatic sensitizers for dye-sensitized solar cells (DSSCs) [10-12]. Indeed, LB films consist of tris(2,2'-bipyridine) ruthenium complex for photocurrent generation systems around $450 \mathrm{~nm}$ have been reported [13]. Then, (ruthenium (II) complex)-bound cellulose derivative seemed to be an attractive as a new complementary material of the porphyrin-bound cellulose derivatives.

In this paper, acetylacetonato-bis(bipyridyl)-ruthenium (II) [acac(bpy) $)_{2} \mathrm{Ru}$ (II)] complex-bound cellulose derivative (3) was selected as a target material for the photocurrent generation performance in the range of $420-600 \mathrm{~nm}$. This was inspired by a report that the coordination reaction of acetoacetyl groups of the polyester with 2,2'-bipyridine complex of ruthenium dichloride (cis-(bpy) $\mathrm{RuCl}_{2}$ ) formed [acac(bpy) ${ }_{2} \mathrm{Ru}$ (II)] complexes [14] and by another report that acetoacetyl cellulose 


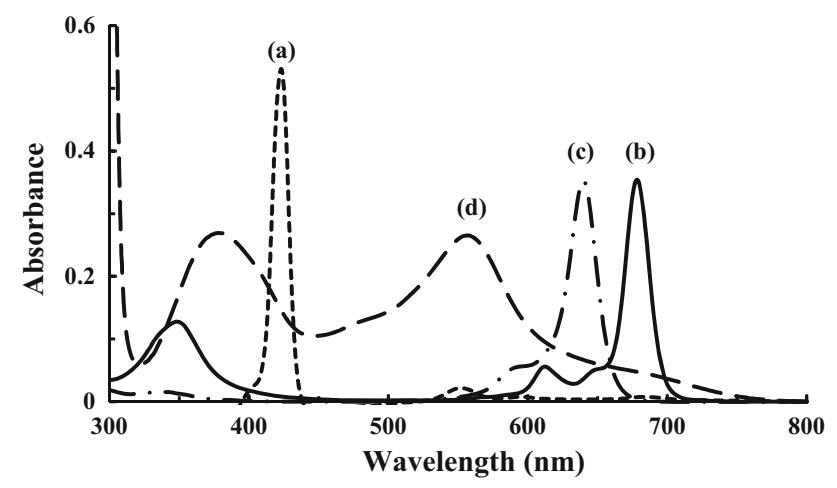

Fig. 1 Target UV-Vis spectra of porphyrin- (a), phthalocyanine- $(b)$, squaraine- $(c)$, and ruthenium (II) complex- $(d)$ bound cellulose derivatives

acted as a metal absorbent [15]. The present paper describes the preparation of compound $\mathbf{3}$ as shown in Fig. 2, the fabrication of its LB monolayer film, and evaluation for photocurrent generation performance of the film.

\section{Materials and methods}

\section{Materials}

2,3-Di-O-myristyl cellulose (1) with degree of substitution of myristyl group (DS $\mathrm{DS}_{\text {mristyl }}$ ) of 1.70 (determined by ${ }^{1} \mathrm{H}$ NMR method) and degree of polymerization $\left(\mathrm{DP}_{\mathrm{n}}\right)$ of 39 $\left(M_{\mathrm{w}} / M_{\mathrm{n}}=1.7\right)$ was prepared according to the reported procedure [7]. 2,2'-Bipyridine complex of ruthenium dichloride dihydrate (cis-(bpy) $\mathrm{RuCl}_{2} \cdot 2 \mathrm{H}_{2} \mathrm{O}$ ) was prepared by the known method [16]. Diketene was distilled from $\mathrm{CaH}_{2}$ under reduced pressure before use. All other
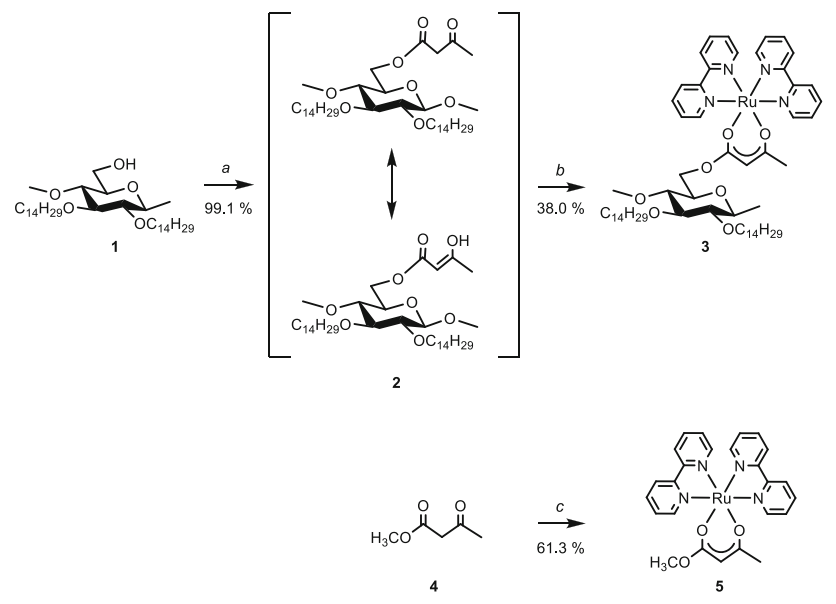

a: diketene/pyridine/THF, $80{ }^{\circ} \mathrm{C}, 6$ h. $b$ : cis-bis(bpy) ${ }_{2} \mathrm{RuCl}_{2} / \mathrm{Et}_{3} \mathrm{~N} / \mathrm{THF}-\mathrm{MeOH}$ $(1: 2, v / v)$, reflux, 48 h. $c$ : $c i s$-bis(bpy $)_{2} \mathrm{RuCl}_{2} / \mathrm{Et}_{3} \mathrm{~N} / \mathrm{MeOH}$, reflux, $8 \mathrm{~h}$

Fig. 2 Synthetic route for 6-O-[acac(bpy) $\left.{ }_{2} \mathrm{Ru}(\mathrm{II})\right]-2,3$-di- $O$-myristyl cellulose (3) and methyl $\left[\operatorname{acac}(\mathrm{bpy})_{2} \mathrm{Ru}(\mathrm{II})\right]$ complex (5) chemicals were purchased from commercial sources and used without further purification.

\section{Measurements}

The ${ }^{1} \mathrm{H}$ and ${ }^{13} \mathrm{C}$ nuclear magnetic resonance (NMR) spectra were recorded on a Varian $500 \mathrm{MHz}$ FT-NMR (500 MHz) spectrometer (Agilent Technologies, Santa Clara, CA, USA) in $\mathrm{CDCl}_{3}$. The chemical shift $(\delta)$ values were given in parts per million (ppm). The Fourier transform infrared (FT-IR) spectra were recorded from $\mathrm{KBr}$ pellets using a Shimadzu IRPrestige-21 spectrophotometer (Shimadzu Co., Kyoto, Japan). The UV-vis spectra were recorded on a Jasco V-560 UV-vis spectrophotometer (Jasco, Tokyo, Japan) in $\mathrm{CHCl}_{3}$. Gel permeation chromatography (GPC) was performed on a Shimadzu LC-10 system equipped with a Shimadzu UV-vis detector (SPD-10Avp) and a Shimadzu RI detector (RID10A) under the following conditions; columns: Shodex columns K-802, K-802.5, and K-805 connected in series (Showa Denko K. K., Tokyo, Japan); column temperature: $40{ }^{\circ} \mathrm{C}$; eluent: $\mathrm{CHCl}_{3}$; flow rate: $1.0 \mathrm{~mL} / \mathrm{min}$; standards: polystyrene standards (Shodex, Showa Denko K.K.).

\section{6-O-Acetoacetyl-2,3-di- $O$-myristyl cellulose (2)}

To a solution of 2,3-di- $O$-myristyl cellulose (1) $(0.400 \mathrm{~g}$, $0.807 \mathrm{mmol}$ ) in tetrahydrofuran (THF, $7 \mathrm{~mL}$ ), pyridine $(0.33 \mathrm{~mL}, \quad 4.03 \mathrm{mmol})$ and diketene $(0.32 \mathrm{~mL}$, $4.03 \mathrm{mmol}$ ) were added. The reaction mixture was stirred at $80{ }^{\circ} \mathrm{C}$ for $6 \mathrm{~h}$. $\mathrm{MeOH}(0.2 \mathrm{~mL})$ was added to the mixture to stop acetoacetylation. The mixture was then concentrated in vacuo to give a residue. The residue was extracted with $\mathrm{CH}_{2} \mathrm{Cl}_{2}$. The organic-layer was washed with distilled water twice, dried with anhydrous $\mathrm{Na}_{2} \mathrm{SO}_{4}$, and concentrated to give a yellow residue. The solution of the residue in $\mathrm{CH}_{2} \mathrm{Cl}_{2}(5 \mathrm{~mL})$ was added to $\mathrm{MeOH}$ $(100 \mathrm{~mL})$ in a drop-wise manner, and the resulting precipitate was collected by centrifugation $(14,000 \times g$, $10 \mathrm{~min})$, washed with $\mathrm{MeOH}$ twice, and dissolved in $\mathrm{CHCl}_{3}(5 \mathrm{~mL})$. The solution was added to $\mathrm{MeOH}$ $(100 \mathrm{~mL})$ in a drop-wise manner, and the resulting precipitate was collected by centrifugation $(14,000 \times g$, $10 \mathrm{~min}$ ), washed with $\mathrm{MeOH}$ twice, and dried in vacuo at $70{ }^{\circ} \mathrm{C}$ overnight to afford compound $2(0.470 \mathrm{~g}, 99.1 \%$ yield). The degree of substitution of acetoacetyl groups $\left(\mathrm{DS}_{\mathrm{acac}}\right)$ of compound $\mathbf{2}$ was calculated based on the area of the methyl groups of acetoacetyl groups (from 2.32 to $2.10 \mathrm{ppm}$ ) and that of the ring-proton of cellulose and the methylene group of myristyl groups (from 5.28 to $2.80 \mathrm{ppm})$ in the ${ }^{1} \mathrm{H}$ NMR spectrum.

Compound 2; $\mathrm{DS}_{\mathrm{acac}}: 1.13 ; \mathrm{DP}_{\mathrm{n}}: 32\left(M_{\mathrm{w}} / M_{\mathrm{n}}=1.94\right)$; ${ }^{1} \mathrm{H} \mathrm{NMR}\left(\mathrm{CDCl}_{3}\right): \delta 12.05-11.92\left(\mathrm{acac}-\mathrm{COCHC}(\mathrm{OH}) \mathrm{CH}_{3}\right.$ (enol form)), 6.20-5.95 (acac- $\mathrm{COCHC}(\mathrm{OH}) \mathrm{CH}_{3}$ (enol 
form)), 5.38-2.80 (CELL ring-H, myristyl-OCH$-\mathrm{OCH}_{2}$, acac$\mathrm{COCH}_{2} \mathrm{COCH}_{3}$ (keto form)), 2.32-2.10 (acac- $\left.\mathrm{CH}_{3}\right)$, 1.60-1.38 (myristyl-OCH${ }_{2} \mathrm{CH}_{2}-$ ), 1.38-1.04 (myristyl$\mathrm{CH}_{2}$ ), 0.96-0.80 (myristyl- $\left.\mathrm{CH}_{3}\right) \mathrm{ppm} ;{ }^{13} \mathrm{C} \mathrm{NMR}\left(\mathrm{CDCl}_{3}\right)$ : $\delta 199.9($ acac-C=O), $166.4($ acac-O-C=O), $102.6(\mathrm{C}-1)$, 82.7 (C-3), 81.9 (C-2), 78.8-70.6 (C-4, myristyl-OCH${ }_{2}-$, C-5), 63.6 (C-6), 49.9, 49.6 (acac- $\mathrm{CH}_{2}-$ ), 31.9, 30.3, 29.7, $29.3,26.3,26.2,26.0,22.6,22.5$ (myristyl- $\mathrm{CH}_{2}-$, acac$\mathrm{CH}_{3}$ ), 14.1 (myristyl- $\mathrm{CH}_{3}$ ) ppm; FT-IR (KBr): $v$ 3435, 2926, 2854, 1751, 1720, 1668, 1635, 1462, 1409, 1361, $1315,1259,1236,1151,1091,1062,918,721,540 \mathrm{~cm}^{-1}$.

\section{6-O-[Acetylacetonato-bis $\left(2,2^{\prime}\right.$ -}

bipyridine)ruthenium(II)]-2,3-di-O-myristyl cellulose (6-O-[acac(bpy) $\left.{ }_{2} \mathrm{Ru}(\mathrm{II})\right]$-2,3-di- $O$-myristyl cellulose) (3)

To a suspension of 6- $O$-acetoacetyl-2,3-di- $O$-myristyl cellulose (2) (34.2 g, $0.581 \mathrm{mmol})$ in THF/MeOH $(1 / 2, \mathrm{v} / \mathrm{v}$, $15 \mathrm{~mL})$, cis-bis(bpy) ${ }_{2} \mathrm{RuCl}_{2} \cdot 2 \mathrm{H}_{2} \mathrm{O}(92.5 \mathrm{mg}, 0.191 \mathrm{mmol})$ and $\mathrm{Et}_{3} \mathrm{~N}(180 \mu \mathrm{L}, 1.29 \mathrm{mmol})$ were added. The reaction mixture was refluxed for $48 \mathrm{~h}$, and added into $\mathrm{EtOH}$ $(100 \mathrm{~mL})$ in a drop-wise manner. The resulting precipitate was removed by centrifugation $(14,000 \times g, 10 \mathrm{~min})$. The supernatant was dialyzed by Spectra/Por dialysis tube $(\mathrm{MWCO}=1000) \quad$ (Spectrum Laboratories Inc., Rancho Dominquez, CA, USA) against $\mathrm{EtOH}$ for 8 days, and concentrated in vacuo to afford compound $\mathbf{3}$ as a red solid (16.8 mg, $38.0 \%$ yield). The $\mathrm{DS}_{\text {Ru-complex }}$ of compound 3 was estimated by UV-Vis method (UV detection: $522 \mathrm{~nm}$ ) with calibration curves from compound $\mathbf{5}$.

Compound 3; $\mathrm{DS}_{\mathrm{Ru} \text {-complex }}$ : 0.42; $\mathrm{DP}_{\mathrm{n}}: 4\left(M_{\mathrm{w}} / M_{\mathrm{n}}=1.44\right)$; ${ }^{1} \mathrm{H} \quad \mathrm{NMR} \quad\left(\mathrm{CDCl}_{3}\right): \delta \quad 9.08-6.84 \quad$ (2-2'-bipyridine- $\left.\mathrm{H}\right)$, 6.19-5.92 (acac-COCHC(OH)CH $\mathrm{CH}_{3}$ (enol form)), 5.20-2.65 (CELL ring-H, myristyl- $\mathrm{OCH}_{2}$, acac- $\mathrm{COCH}_{2} \mathrm{COCH}_{3}$ (keto form) ), 2.45-1.70 (acac- $\mathrm{CH}_{3}$ ), 1.70-1.42 (myristyl-OCH $\mathrm{CH}_{2}$ ), 1.42-1.00 (myristyl- $\mathrm{CH}_{2}^{-}$), 1.00-0.80 (myristyl- $\mathrm{CH}_{3}$ ) ppm; FT-IR (KBr): v 3425, 2924, 2852, 1741, 1716, 1668, 1627, 1597, 1560, 1541, 1506, 1462, 1419, 1367, 1311, 1265, $1153,1068,798,767,725 \mathrm{~cm}^{-1}$; UV-Vis (in $\left.\mathrm{CHCl}_{3}\right): \lambda(\log$ ع) 522 (3.6), 370 (3.6), 297 (4.3), 250 (4.2) nm.

\section{Methyl acetylacetonato bis $\left(2,2^{\prime}\right.$ - bipyridine)ruthenium (II) complex (5)}

To a suspension of $\quad$ cis-bis(bpy $)_{2} \mathrm{RuCl}_{2} \quad$ (32.1 mg, $0.0663 \mathrm{mmol})$ in $\mathrm{MeOH}(10 \mathrm{~mL})$, methyl acetoacetate (4) $(27 \mu \mathrm{L}, 0.247 \mathrm{mmol})$ and $\mathrm{Et}_{3} \mathrm{~N}(61 \mu \mathrm{L}, 0.438 \mathrm{mmol})$ were added. The reaction mixture was refluxed for $8 \mathrm{~h}$, and concentrated in vacuo to give a crude product. The product was purified by silica gel column chromatography using $10 \%$ $\mathrm{MeOH} / \mathrm{CH}_{2} \mathrm{Cl}_{2}(v / v)$ as an eluent, followed by preparative thin-layer chromatography developed with $10 \% \mathrm{MeOH} /$ $\mathrm{CH}_{2} \mathrm{Cl}_{2}$ to yield compound 5 as a red solid (21.5 mg, $61.3 \%$ ).

Compound 5; ${ }^{1} \mathrm{H}$ NMR $\left(\mathrm{CDCl}_{3}\right): \delta 8.84(\mathrm{~d}, 1 \mathrm{H}, J=8.0)$, $8.77(\mathrm{~d}, 1 \mathrm{H}, J=4.5), 8.75-8.67(\mathrm{~m}, 3 \mathrm{H}), 8.52(\mathrm{~d}, 1 \mathrm{H}$, $J=8.0), 8.18-8.10(\mathrm{~m}, 2 \mathrm{H}), 7.84(\mathrm{t}, 1 \mathrm{H}, J=7.5), 7.76(\mathrm{t}$, $1 \mathrm{H}, J=7.5), 7.66-7.60(\mathrm{~m}, 4 \mathrm{H}), 7.14(\mathrm{t}, 1 \mathrm{H}, J=6.2), 7.09$ $(\mathrm{t}, 1 \mathrm{H}, J=6.5)\left(2,2^{\prime}\right.$-pyridinyl- $\left.H\right), 4.75(\mathrm{~s}, 1 \mathrm{H}, \mathrm{CH}), 3.34(\mathrm{~s}$, $\left.3 \mathrm{H},-\mathrm{OCH}_{3}\right), 1.82\left(\mathrm{~s}, 3 \mathrm{H},-\mathrm{CH}_{3}\right) \mathrm{ppm} ;{ }^{13} \mathrm{C} \mathrm{NMR}\left(\mathrm{CDCl}_{3}\right): \delta$ $188.4(C=\mathrm{O}), 170.2(-\mathrm{C}=C(\mathrm{OH})-), 159.7,159.3,158.18$, $158.15,153.1,152.6,150.3,149.9,136.7,136.3,135.3,134.7$, $126.1,126.0,125.5,125.4,124.0,123.8,123.7,123.5\left(2.2^{\prime}-\right.$ bypyridyl- $C), 83.5(\mathrm{CH}), 51.6\left(-\mathrm{OCH}_{3}\right), 27.8\left(-\mathrm{CH}_{3}\right) \mathrm{ppm}$; FT-IR (KBr): $v$ 3429, 3061, 3010, 2949, 2760, 2659, 2482, 1595, 1508, 1456, 1419, 1274, 1180, 1064, 1014, 804, 767, 731, 657, $638 \mathrm{~cm}^{-1}$; UV-Vis (in $\mathrm{CHCl}_{3}$ ): $\lambda(\log \varepsilon) 527$ (3.8), 372 (3.9), 297 (4.6), 250 (4.4) nm.

\section{Preparation and characterization of LB monolayer film of compound 3}

The LB monolayer films of compound $\mathbf{3}$ were prepared according to the reported procedure [7]. The photocurrent measurements were performed according to the method reported by Sakakibara and Nakatsubo [5].

\section{Results and discussion}

\section{Synthesis of 6-O-[acac(bpy $\left.)_{2} \operatorname{Ru}(\mathrm{II})\right]-2,3-\mathrm{di}-O$ - myristyl cellulose (3)}

Acetoacetylation of 2,3-di- $O$-myristyl cellulose (1) was carried out using the method for wood meal [17] to give compound $\mathbf{2}$ in $99 \%$ yield. The characteristic $\beta$-ketoester bands at 1751 and $1720 \mathrm{~cm}^{-1}$ [18] appeared in the FT-IR spectrum of compound 2 (Fig. 3b), suggesting that acetoacetylation of compound $\mathbf{1}$ proceeded smoothly. The signals derived from acetoacetyl groups around $2.20 \mathrm{ppm}$ in the ${ }^{1} \mathrm{H}$ NMR spectrum of compound 2 and those derived from carbonyl groups at 199.9 and 166.4 ppm [15] in the ${ }^{13} \mathrm{C}$ NMR spectrum also supported successful synthesis of compound 2 . The equilibrium between the enol and keto forms of the $\beta$-diketones has been reported [19]. Indeed, the equilibrium was found in the ${ }^{1} \mathrm{H}$ NMR spectrum of compound $\mathbf{2}$, that is, the signals assigned to hydroxyl groups $(-\mathrm{OH})$ and vinyl protons $(-\mathrm{CH}=)$ of the enol structure of acetoacetyl groups around 12.0 and $6.10 \mathrm{ppm}$ $[14,19]$ were clearly found, although the signals assigned to methylene protons $\left(-\mathrm{CH}_{2}-\right)$ of the keto structure of acetoacetyl groups overlapped with the signals of cellulose ring protons and methylene groups $\left(-\mathrm{OCH}_{2}-\right)$ of myristyl groups. The $\mathrm{DS}_{\mathrm{acac}}$ of compound $\mathbf{2}$ was calculated to be 


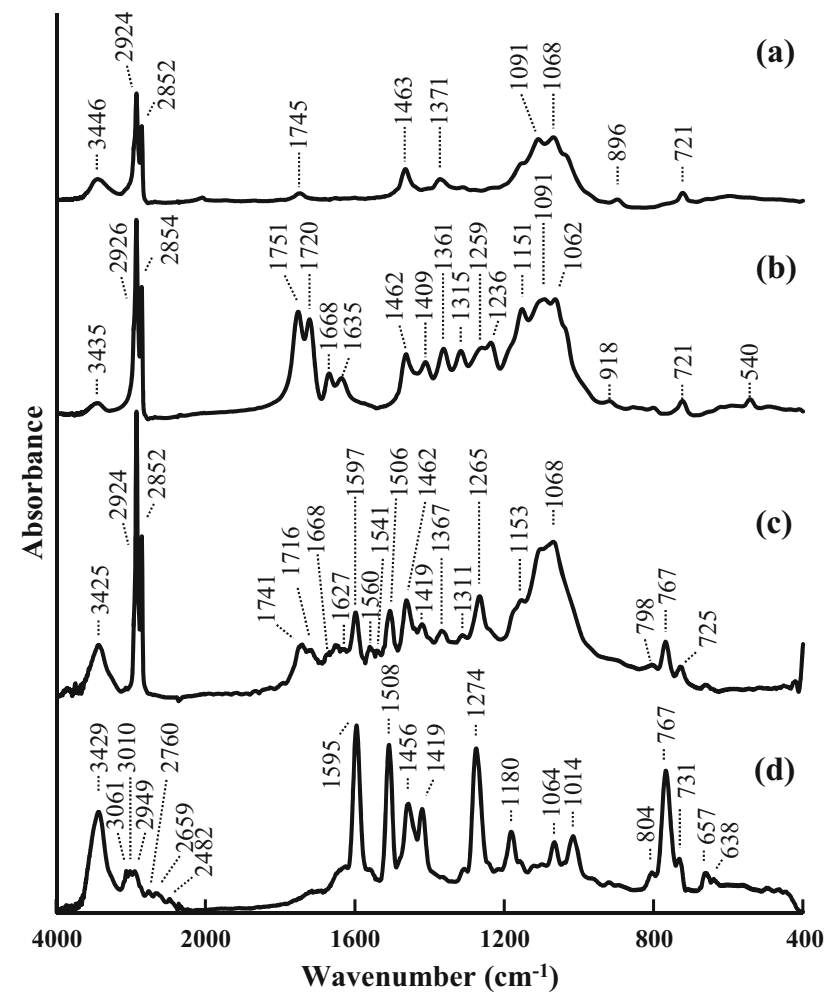

Fig. 3 FT-IR spectra of compounds (a) 1, (b) 2, (c) $\mathbf{3}$ and (d) $\mathbf{5}$

1.13 by ${ }^{1} \mathrm{H}$ NMR method. Compound 2 was soluble in $\mathrm{CHCl}_{3}, \mathrm{CH}_{2} \mathrm{Cl}_{2}, \mathrm{ClCH}_{2} \mathrm{CH}_{2} \mathrm{Cl}$ and THF, but insoluble in $\mathrm{MeOH}, \mathrm{DMSO}$ and DMF.

First, the coordination reaction of compound 2 with cisbis(bpy $)_{2} \mathrm{RuCl}_{2} \cdot 2 \mathrm{H}_{2} \mathrm{O}$ was performed under the reaction conditions $\left(\mathrm{Et}_{3} \mathrm{~N} / \mathrm{THF} / \mathrm{reflux} / 48 \mathrm{~h}\right)$ [14]. However, compound 3 could not be obtained. The reason might be caused by poor solubility of cis-bis(bpy) $\mathrm{RuCl}_{2} \cdot 2 \mathrm{H}_{2} \mathrm{O}$ in THF. Then, the coordination reaction of compound 2 was performed in THF-MeOH $(1: 2, v / v)$ in the presence of $\mathrm{Et}_{3} \mathrm{~N}$ under reflux for $48 \mathrm{~h}$ to give compound $\mathbf{3}$ as a red solid in $38.0 \%$ yield, although the purification was a tedious and time-consuming work. Compound $\mathbf{5}$ was also prepared as an authentic sample by the reaction of methyl acetoacetate (4) with cis-bis(bpy) ${ }_{2} \mathrm{RuCl}_{2}$ in $\mathrm{ClCH}_{2} \mathrm{CH}_{2} \mathrm{Cl}$ in the presence of $\mathrm{Et}_{3} \mathrm{~N}$. Compound $\mathbf{3}$ was subjected to FT-IR, NMR, UV-Vis and GPC measurements. The characteristic enolform bands at 15971506,1265 and $767 \mathrm{~cm}^{-1}$ [20] were clearly observed in the FT-IR spectrum of compound $\mathbf{3}$ (Fig. 3c). The presence of bipyridyl groups was confirmed by the ${ }^{1} \mathrm{H}$ NMR spectrum of compound 3 . Furthermore, the $\mathrm{UV}-\mathrm{Vis}$ spectrum of compound $\mathbf{3}$ had the same profile as that of compound 5 (Fig. 4). These results suggested that the coordination reaction proceeded successfully. However, the DP of compound $\mathbf{2}$ decreased significantly during

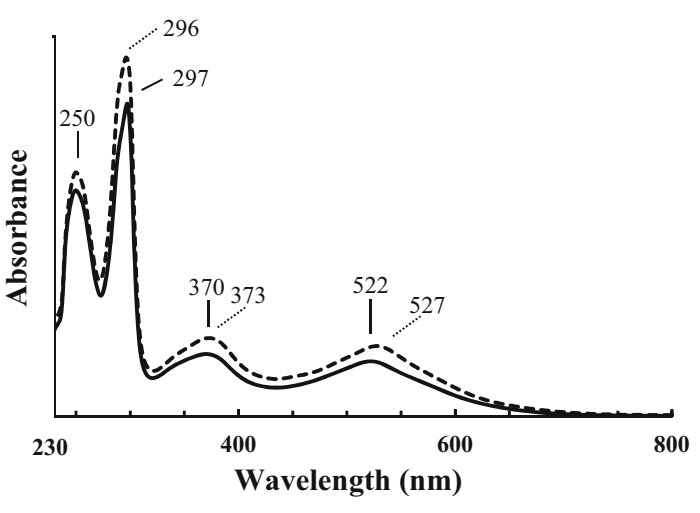

Fig. 4 UV-Vis spectra of compounds 3 (solid line) and 5 (dotted line) in $\mathrm{CHCl}_{3}$

the coordination reaction. The $\mathrm{DS}_{\mathrm{Ru} \text {-complex }}$ was calculated to be 0.42 by UV-Vis method with calibration curves made by compound $\mathbf{5}$.

\section{Preparation and characterization of LB monolayer film of compound 3}

The surface pressure $(\pi)$-area $(A)$ isotherms of compounds $\mathbf{1}$ and $\mathbf{3}$ at the air-water surface at $20^{\circ} \mathrm{C}$ are shown in Fig. 5 . The degree of slope and collapsed pressure in the isotherm of compound $\mathbf{3}$ was similar to the corresponding degree and pressure in that of compound $\mathbf{1}$, although the limiting area of compound $\mathbf{3}\left(0.83 \mathrm{~nm}^{2} / \mathrm{AGU}\right)$ was somewhat larger than that of compound $1\left(0.60 \mathrm{~nm}^{2} / \mathrm{AGU}\right)$, but was smaller than that of phthalocyanine-bound cellulose derivative $\left(1.11 \mathrm{~nm}^{2} / \mathrm{AGU}\right)$ reported in the previous paper [8]. These results suggested the low DP of compound 3 did not significantly influence the LB film fabrication. Indeed, LB monolayer film of compound $\mathbf{3}$ could be successfully deposited onto an indium tin oxide (ITO) electrode by a vertical dipping method at a surface pressure at deposition of $10 \mathrm{mN} / \mathrm{m}$. The transfer ratio of the $\mathrm{LB}$ monolayer film was 0/1.38 (downward/upward strokes), indicating that the film is a Z-type film.

The photoelectrochemical response of the LB monolayer film of compound $\mathbf{3}$ when irradiated by the light at $510 \mathrm{~nm}$ is shown in Fig. 6a. A steady-state anodic photocurrent appeared upon light illumination. The action spectrum (the relationship between generating photocurrent and wavelength of the irradiated light) of film $\mathbf{3}$ from 400 to $800 \mathrm{~nm}$ is also shown in Fig. 6b; the spectrum at less than $400 \mathrm{~nm}$ could not be measured because of lack of interference filters (less than $400 \mathrm{~nm}$ ) in our laboratory. The action spectrum was similar to the absorption spectrum of compound 3 in $\mathrm{CHCl}_{3}$, indicating that the ruthenium complex moieties in compound $\mathbf{3}$ serves as the photoactive species for the photocurrent generation in the region of $400-600 \mathrm{~nm}$. The photocurrent density (photocurrent per 


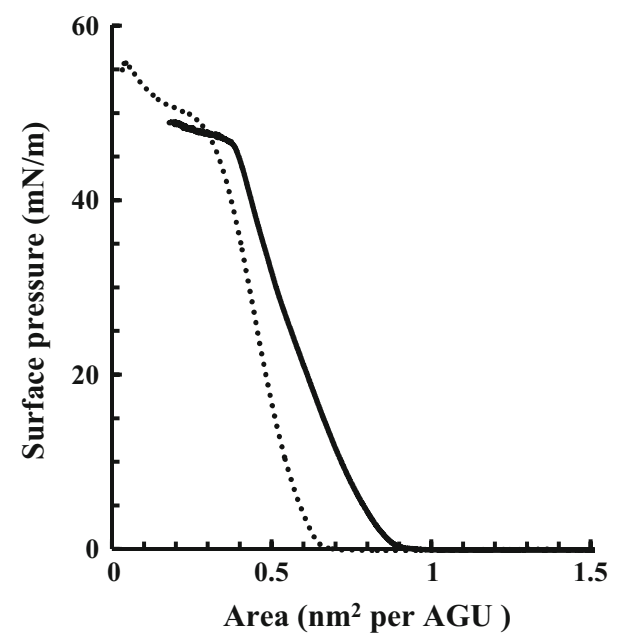

Fig. 5 Surface pressure $(\pi)$-area $(A)$ isotherms of compounds 1 (dotted line) and $\mathbf{3}$ (solid line)
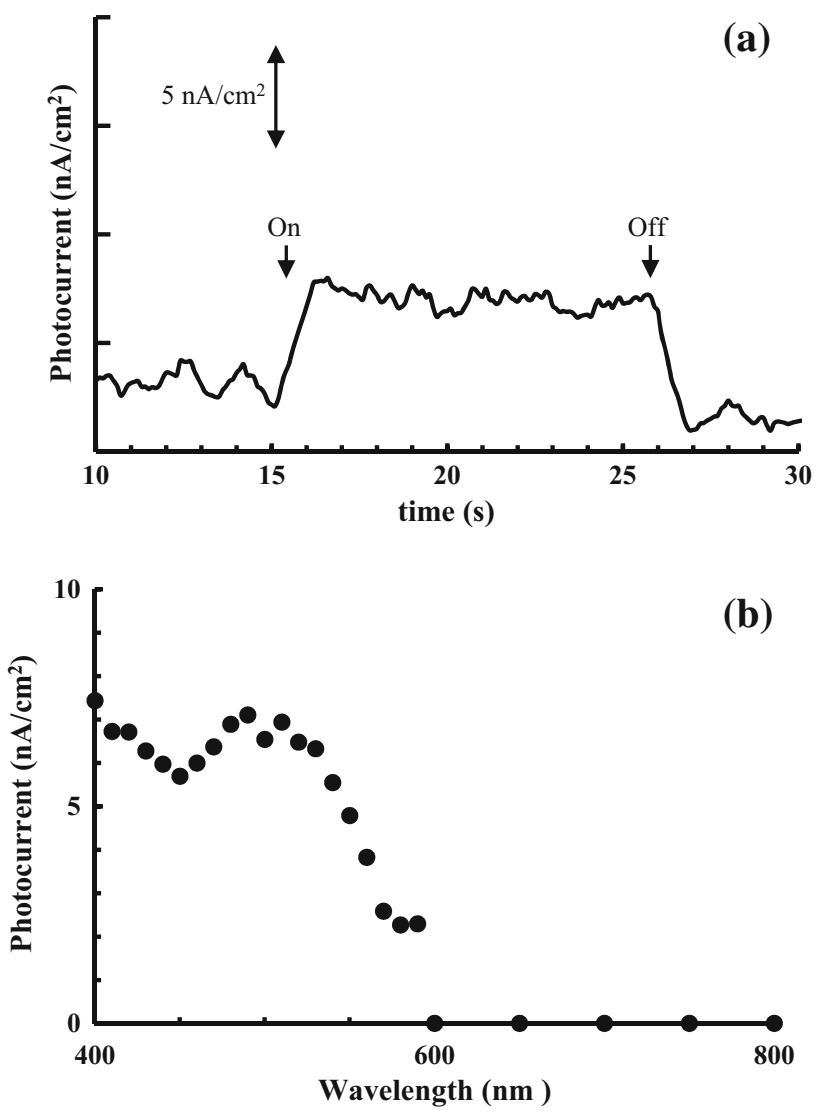

Fig. 6 a Photoelectrochemical response of the LB monolayer film of compound $\mathbf{3}$ with illumination at $510 \mathrm{~nm}$, and $\mathbf{b}$ action spectrum of the film of compound $\mathbf{3}$

unit area of a working electrode) of film 3 at $510 \mathrm{~nm}$ was found to be $7.10 \mathrm{nA} / \mathrm{cm}^{2}$, although further improvement of the photocurrent density is required.

\section{Conclusion}

6-O-[Acac(bpy) $\left.{ }_{2} \mathrm{Ru}(\mathrm{II})\right]-2,3$-di-O-myristyl cellulose (3) was prepared from 2,3-di- $O$-myristyl cellulose (1) by two reaction steps in $37.7 \%$ total yield. The LB monolayer film of compound $\mathbf{3}$ was successfully deposited onto ITO electrode by a vertical dipping method, suggesting the low DP of compound 3 did not influence the LB film fabrication. It showed photocurrent generation performance in the range of 400-600 nm in which LB films of other photosensitizer-bound cellulose derivatives did not generate photocurrent. Compound $\mathbf{3}$ is expected to be a third complementary material of porphyrin-bound cellulose derivative for biomaterial-based solar cells, as well as phthalocyanine-bound cellulose derivatives $[7,8]$ and squaraine-bound cellulose derivative [9]. It is thought that the low DP of compound $\mathbf{3}$ might be covered by the combination of other photosensitizer-bound cellulose derivatives with high DP.

\section{References}

1. Kang H, Liu R, Huang Y (2012) Cellulose derivatives and graft copolymers as blocks for functional materials. Polym Int 62:338-344

2. Wondraczek H, Kotiaho A, Fardim P, Heinze T (2011) Photoactive polysaccharides. Carbohydr Polym 83:1048-1061

3. Edgar KJ, Buchanan CM, Debenham JS, Rundquist P, Seiler BD, Shelton MC, Tindall D (2001) Advances in cellulose ester performance and application. Progress Polym Sci 26:1605-1688

4. Sakakibara K, Ogawa Y, Nakatsubo F (2007) First cellulose Langmuir-Blodgett films towards photocurrent generation systems. Macromol Rapid Commun 28:1270-1275

5. Sakakibara K, Nakatsubo F (2010) Effect of central metals in the porphyrin ring on photocurrent performance of cellulose Langmuir-Blodgett films. Macromol Chem Phys 211:2425-2433

6. Burke A, Schmidt-Mende L, Ito S, Grätzel M (2007) A novel blue dye for near-IR "dye-sensitised" solar cell applications. Chem Commun 234-236

7. Saito Y, Takano T, Sakakibara K, Kamitakahara H, Nakatsubo F (2012) Synthesis of (zinc(II) phthalocyanine)-containing cellulose derivative using phthalocyanine-ring formation reaction. Cellulose 19:2105-2114

8. Saito Y, Kamitakahara H, Takano T (2014) Preparation of Langmuir-Blodgett monolayer films of (zinc(II) phthalocyanine)containing cellulose derivative; the use of 2,3-di- $O$-myristyl cellulose as a scaffold. Cellulose 21:1885-1896

9. Saito Y, Kamitakahara H, Takano T (2016) Preparation of a squaraine-bounded cellulose derivative for photocurrent generation system. Carbohydr Res 421:40-45

10. Numata Y, Zhang S, Yang X, Han L (2013) Consensitization of ruthenium-polypyridyl dyes with organic dyes in dye-sensitized solar cells. Chem Lett 42:1328-1335

11. Yin J-F, Velayudham M, Bhattacharya D, Lin H-C, Lu K-L (2012) Structure optimization of ruthenium photosensitizers for efficient dye-sensitized solar cells - a goal toward a "bright" future. Coord Chem Rev 256:3008-3035 
12. Vougioulalakis GC, Philippopoulos A, Stergiopoulos T, Falaras P (2011) Contributions to the development of ruthenium-based sensitizers for dye-sensitized solar cells. Coord Chem Rev 255:2602-2621

13. Taniguchi T, Miyashita T (1997) Photoelectrochemical responses of polymer Langmuir-Blodgett films containing tris $\left(2,2^{\prime}\right.$ bipyridine)ruthenium(II) complex. Chem Lett 26:295-296

14. Matsumi N, Nakamura N, Aoi K (2008) Novel bio-based polyesters derived from curcumin as an inherent natural diol monomer. Polym J 40:400-401

15. Edgar KJ, Arnold KM, Blount WW, Lawniczak JE, Lowman DW (1995) Synthesis and properties of cellulose acetoacetates. Macromolecules 28:4122-4128

16. Sullivan BP, Salmon DJ, Meyer TJ (1978) Mixed phosphine 2,2'bipyridine complexes of ruthenium. Inorg Chem 17:3334-3341

17. Nasuno T, Takano T, Yoshimura T, Kamitakahara H, Nakatsubo F (2006) Preparation of acetoacetylated wood meal and its properties: part 1. Preparation of parameter and preliminary evaluation of the antifungal activity. Holzforschung 60:201-205

18. Yoshida Y, Isogai A (2007) Preparation and characterization of cellulose $\beta$-ketoesters prepared by homogeneous reaction with alkylketene dimers: comparison with cellulose/fatty acid esters. Cellulose 14:481-488

19. Wallen SL, Yonker CR, Phelps CL, Wai CM (1997) Effect of fluorine substitution, pressure and temperature on the tautomeric equilibria of acetylacetonate $\beta$-diketones. J Chem Soc Faraday Trans 93:2391-2394

20. El-Hendawy AM, Al-Kubaisi AH, Al-Madfa HA (1997) Ruthenium (II) and (III) bipyridine complexes and their catalytic oxidation properties for organic compounds. Polyhedron 16:3039-3045 